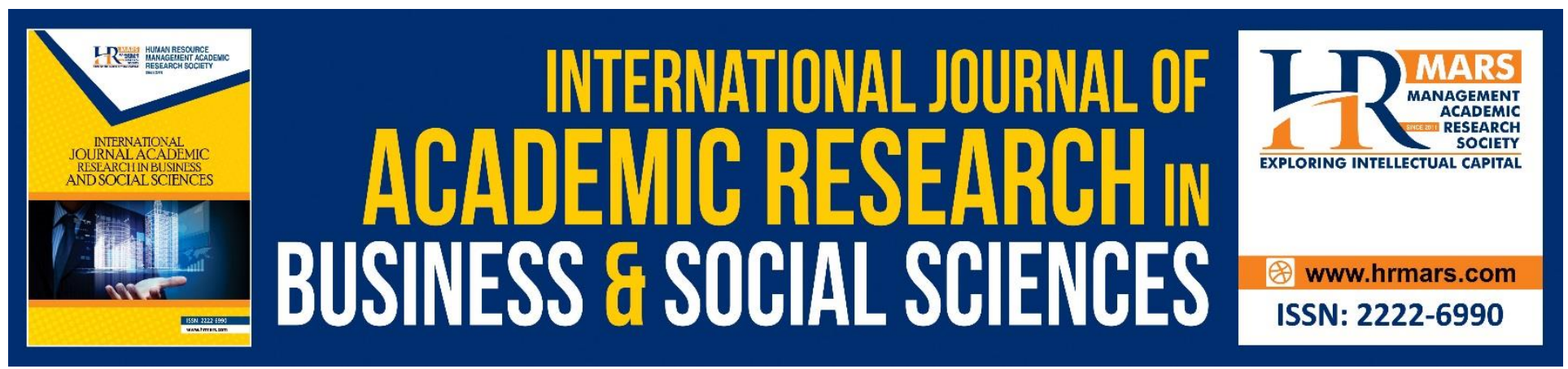

\title{
Relationship between the Pre-Election Phase Processes and Political Stability in the East African Community States
}

Rwigema Pierre Celestin, Mike A. Iravo, Gregory Namusonge

To Link this Article: http://dx.doi.org/10.6007/IJARBSS/v8-i8/4528

DOI: $\quad 10.6007 /$ IJARBSS/v8-i8/4528

Received: 07 July 2018, Revised: 26 July 2018, Accepted: 29 July 2018

Published Online: 18 August 2018

In-Text Citation: (Celestin, Iravo, \& Namusonge, 2018)

To Cite this Article: Celestin, R. P., Iravo, M. A., \& Namusonge, G. (2018). Relationship between the Pre-Election Phase Processes and Political Stability in the East African Community States. International Journal of Academic Research in Business and Social Sciences, 8(8), 458-475.

Copyright: (C) 2018 The Author(s)

Published by Human Resource Management Academic Research Society (www.hrmars.com)

This article is published under the Creative Commons Attribution (CC BY 4.0) license. Anyone may reproduce, distribute, translate and create derivative works of this article (for both commercial and non-commercial purposes), subject to full attribution to the original publication and authors. The full terms of this license may be seen at: http://creativecommons.org/licences/by/4.0/legalcode

Vol. 8, No. 8, August 2018, Pg. 458 - 475

Full Terms \& Conditions of access and use can be found at http://hrmars.com/index.php/pages/detail/publication-ethics 


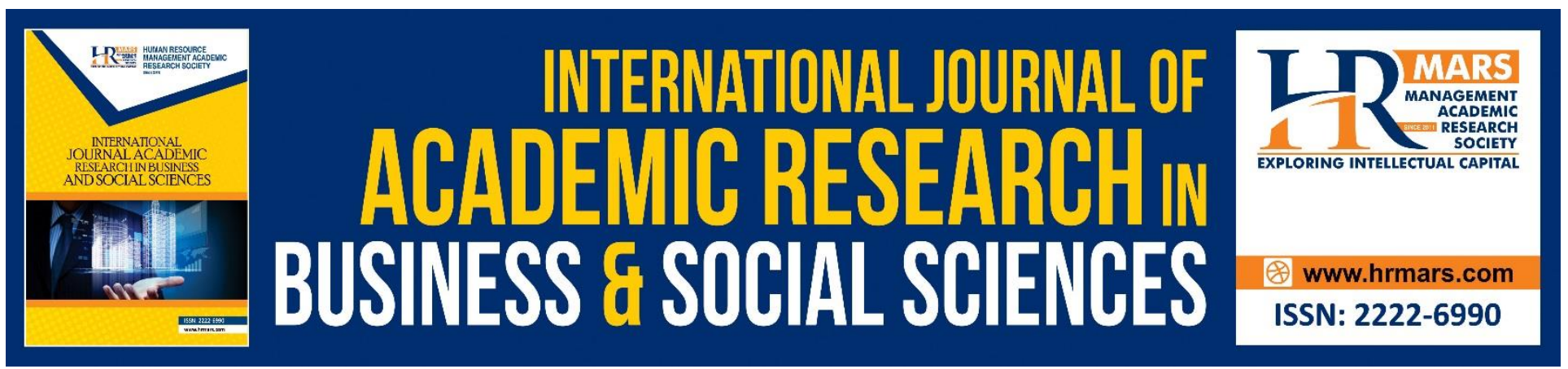

\title{
Relationship between the Pre-Election Phase Processes and Political Stability in the East African Community States
}

\author{
Rwigema Pierre Celestin \\ Jomo Kenyatta University of Agriculture and Technology, Kigali, Rwanda. \\ Prof. Mike A. Iravo \\ Jomo Kenyatta University of Agriculture and Technology, Kenya \\ Prof. Gregory Namusonge \\ Jomo Kenyatta University of Agriculture and Technology, Kenya
}

\begin{abstract}
The purpose of the study was to determine the relationship between the pre-election phase processes and political stability in the East Africa Community States. This study adopted a quantitative approach of both descriptive and correlation designs. The target population consisted of 123 individuals working within the electoral commissions of different EAC Countries and the EAC Legislative Assembly. Primary data were collected using self-administered questionnaire. The study used primary data, which was collected using questionnaires. The questionnaires were both open and close ended. The study used email, phone calls and meeting procedure with the targeted respondent in EAC Countries and the EAC Legislative Assembly to follow up. Data collected from the field were coded, cleaned and categorized according to questionnaire items. A pilot test was conducted to detect weaknesses in design and instrumentation. The gathered data was analyzed using computer aided IBM Statistical Package for Social Sciences (SPSS) version 21 premium. Both descriptive and inferential statistics was used to analyze the data collected. Descriptive statistics involved computation of mean scores, standard deviation, percentages, cross tabulation and frequency distribution which described the demographic characteristics of the organization and the respondents. Inferential statistics was used to determine the relationships and significance between independent and dependent variable. Correlation and linear regression were used to analyze the data with F-test being applied to the test hypothesis at $5 \%$ level of significance. Content analysis was used for the qualitative data. The data was presented using tables, graphs and charts. From this objective, it was hypothesized that there is no relationship between pre-election phase processes and political stability in the East African Community States. The results of this study showed a positive statistically
\end{abstract}


INTERNATIONAL JOURNAL OF ACADEMIC RESEARCH IN BUSINESS AND SOCIAL SCIENCES

Vol. 8, No. 8, August 2018, E-ISSN: 2222-6990 @ 2018 HRMARS

significant relationship between pre-election phase processes and political stability in the East African Community States. Therefore, hypothesis H01: there is no significant relationship between preelection phase processes and political stability in the East African Community States was rejected and concluded that pre-election phase processes have a significant effect on political stability. It is notable that the relationship at this stage was not as strong as expected. The researcher attributes this to the fact that before election process it is still young, and the states are at initial stage of implementation of election campaigns and rules.

Keywords: Pre-election phase processes, Political stability, East African Community States.

\section{Introduction}

Globally elections play a significant role in peace processes since they are widely considered to be the main method of achieving a peaceful resolution to political controversies (Levitsky \& Way 2010). An election process is a means of pursuing or retaining political power in which social differences are highlighted by candidates and parties campaigning for popular support (Frantz \& Geddes 2013). This process can contribute to peace, but it can also provide entry points for violence and conflicts because of the competitive patterns embedded in the "winner-loser" dichotomy (Norman, 2013). Such instability can derail the peace process and hamper both short-term recovery efforts and longterm development (Kilonzo, 2009).

The last quarter of the twentieth century witnessed the greatest expansion of democracy in the history of the world (Mudde 2013). If we define democracy in the minimal sense, as a system of government in which the principal positions of political power are filled through regular, free, and fair elections, then about three of every five independent states in the world are democracies today (Mudde \& Kaltwasser 2013).

Most countries in the world regard periodic and regular elections as a core attribute of democracy. In 2016, a total of 132 elections were held worldwide in presidential, legislative or local contests (International IDEA 2017). Electoral processes held under conditions that meet global and regional standards for being credible give meaning to democracy's core values of political equality and the accountability of those who govern. At a basic and practical level, elections are a critical element of an effective anti-corruption strategy, even if the fear of losing an election is not always enough to prevent elected officials from being corrupt.

The United States of America is considered a democratic state which holds elections after every four years. Candidates for each political party declare interest but the final candidate for a given party is chosen at party meetings called conventions. The parties hold conventions at the local, state and national levels. There are two main ways the states send people to the national convention: the caucus and the primary. Both methods result in a set of delegates who attended the national conventions. The delegates pledge that when they attend the convention, they voted for the candidate the state political party supports. In terms of campaign funding, millions of dollars are spent in the months leading up to the national conventions, but that is just the beginning. Once the field is narrowed to the two main party candidates, fundraising becomes even more important. There are only a few months before the general election, and each candidate needs to get his or her message out to the American public. The parties in each state help the candidates with paying the bills and organizing support (Thad, 2012).

The UK is a constitutional monarchy comprising England, Wales, Scotland, and Northern Ireland. A bicameral parliament exercises legislative authority through the House of Lords and the House of Commons. The 650 members of the House of Commons are elected under a first- past-the-post 
system in single-member constituencies for a fixed 5-year period. Candidates who receive the highest numbers of valid votes in each constituency are elected (Blau \& Adrian, 2008).

According to the Australian Education Office (2009), Australia is a representative democracy, founded in the liberal democratic tradition. This means that the people vote for candidates from among multiple political parties to represent their interests in parliament; and the decision- making power of elected representatives is subject to the rule of law. The Constitution, together with statute and common law, protects the rights and freedoms of individuals and minority groups such that diverse political interests are acknowledged; and all Australians are entitled to procedural fairness in the resolution of disputes. The Constitution sets out the roles and powers of the national parliament, the government and the courts. It guarantees the protection of certain rights and freedoms defines the responsibilities of the Commonwealth government (such as foreign relations, trade, defense, immigration and taxation) and places constraints on government authority.

The over seer of elections in India is the Election Commission of India which is established under the Indian Constitution. The Election Commission of India is an autonomous, constitutionally established federal authority responsible for administering all the electoral processes in the Republic of India. Under the supervision of the commission, free and fair elections have been held in India at regular intervals as per the principles enshrined in the Constitution (Gill, 2008). Art 325 of the constitution provides for creation of a single election roll for entire country. There is an Election Commission of India at National level and State Election Commissions at State level to administer the electoral process in India. Constitution of India in Art 324 provides for an Election Commissioner and other Election commissioners, who are appointed by the president of India. The chief election commissioner functions as the chairperson of the commission. India recognizes democracy as being extremely important and strives to conduct free and fair elections to establish the legitimacy of political leaders. India is by far the largest democracy in the world with more than 800 million voters, and the conduct of free, fair and fast elections is a very challenging and a daunting task. Electronic Voting Machines (EVMs) were introduced as an effort to improve and strengthen the method of electoral process. In particular its objective was to minimize incidences of human error, reduce instances of rigging and manipulation, and prevent abuse of government power in polls. In addition, the use EVMs were also justified in terms of "commendable" reduction in cost and time involved in the conduct of elections and increase the likelihood of being able to cast votes by the vulnerable sections (Shri Mohan, 2011).

The stakeholders in the South African political arena acknowledge the fact that elections and electoral systems are vital indicators of the level and extent of democratic consolidation. The South African Constitution guarantees universal adult suffrage, a national common voter's roll and regular elections (Teorell \& Lindstedt, 2010). It provides for a national assembly consisting of no fewer than 350 and no more than 400 men and women elected as members under an electoral system based on a national common voter's roll and results. It also provides for a minimum voting age of 18 years (Kadima and Leonard 2009). The Constitution provides for provincial legislatures consisting of representatives elected as members in the same fashion as those elected to the national legislature save that such election is based on the province's segment of the national common voter's roll.

Albertyn, et al (2012) explains that in accordance with the constitutional requirements, South Africa uses a proportional representation (PR) electoral system, based on fixed party lists. Half of the 400 national assembly members are chosen from nine provincial lists and the other half from a single national list prepared by each party. Provincial parliaments are chosen from the party lists for each provincial legislature. They assert that this ensures an almost complete proportionality with no votes 
'wasted'. The Droop quota is used to apportion seats: this quota results in seats being awarded through the largest remainder method. If a seat is left unfilled after all allocations have been made, the political party with the highest remainder of unallocated votes were given that seat. No mandatory threshold for parliamentary representation exists, thus ensuring inclusiveness by enabling even very small parties' representation in parliament.

Ghana's political system is a mixture of Westminster and a presidential system, with the office of the president endowed with far-reaching powers and the executive playing the legislative (Lindberg, 2010). Under the Constitution, Ghana's judicial system is relatively well developed, although even the judiciary is not wholly free of political influence and bribery. Currently, the president and the parliamentary elections follow the first-past-the-post electoral system whereby the people elect the President and their deputies directly. Although parliamentary elections are by a simple majority, the president on the other hand needs an absolute majority to win such that if no candidate emerges victorious from the first ballot, a run- off is held between the two frontrunners to determine the winner (Smith 2011).

Kenya's electoral process is hinged on the constitution which directly addresses most of the sequences. However, parliament also has a lee way to address some of the processes through different Acts. According to Pepela (2015), the electoral process in Kenya is conducted by the independent electoral and boundaries commission which is headed by a commission chairman. The elections are conducted after every five years unless in the instances that a by-election is announced for a certain parliamentary or county seat. The Constitution (2010) on which the electoral process is leveraged has a strong link to political stability as determined by the electoral system and management of elections. The Constitution of Kenya (2010) gives the general principles for the electoral system which must be complied with before, during and after elections. Some of the principles include the following: Freedom of citizens to exercise their political rights under Article 38 of the constitution, not more than two-thirds of the members of elective public bodies shall be of the same gender; fair representation of persons with disabilities; universal suffrage based on the aspiration for fair representation and equality of vote; and free and fair elections, which are: by secret ballot; free from violence, intimidation, improper influence or corruption; conducted by an independent body; transparent; and administered in an impartial, neutral, efficient, accurate and accountable manner.

The qualified voters are then given votes cards which are kept safely for use on the particular day of voting. This is normally followed by checking of voters register after the voter registration process is over whereby the registered voters are given an opportunity to go back to the areas where they registered so as to confirm whether their names appear on the voters' register. They also find out whether their names are spelt correctly this in some cases is also done electronically. Educating voters is compulsory according to the election Act 2012. Voters are educated on how to vote through advertisement, workshops, media awareness and other congregations throughout the country. The people are also informed on the importance of voting. Conducting elections is held transparently by ensuring that candidates have their agents at the polling stations that make sure the ballot boxes and vote counting are effectively managed. The voters then elect members of their choice. Counting votes and announcement of results is done at the polling stations and the presiding officer delivers results to the presiding officer at the constituency level. The returning officer after compiling all the results from presiding officers announces the results of the parliamentary elections. The results are then submitted to the IEBC headquarters for official announcement (Kathurima, 2011). The hearing and 
determination resolution of electoral disputes on the election of the president is done under the jurisdiction the created Supreme Court which was created by the Constitution 2010.

The electoral system in Uganda is generally prescribed in the Constitution and the relevant laws. Executive authority of Uganda lies with the President who is the Head of State and Commander in Chief of Uganda Peoples Defense Forces and the Fountain of Honor and who takes precedence over all persons in Uganda. The Constitution establishes an Electoral Commission as an independent commission; a body corporate, consisting of a chairperson, a deputy chairperson and five (5) other members, appointed by the President with approval of Parliament. Members of the Commission must be persons of high moral character, proven integrity, with considerable experience and demonstrated competence in the conduct of public affairs and must hold office for 7 years. Their appointment may be renewed for one more term only (IPU, 2015).

Role of crime preventers: Claims had been made that there was ongoing recruitment and training of militia by the NRM, to harass and intimidate citizens in constituencies, as well as the establishment of 'vote protecting brigades' by opposition parties. Concerns were expressed about the potential threats associated with the recruitment of such forces in the absence of a legal framework to embed accountability. The police had acknowledged that crime preventers were being recruited to boost the capacity of police at polling stations on Election Day, by performing the role of 'electoral constables, Commonwealth (2016).

Tanzania is a Union of formerly sovereign states which are Tanganyika (now Mainland Tanzania) and Zanzibar (now Tanzania Zanzibar). Tanzania is a democratic country with a Multi-party-political system since July 1992. In accordance with Article 3 (1) of the Constitution of the United Republic of Tanzania, 1977. Tanzania and Zanzibar's electoral framework is based on a First-Past-The Post (FPTP) system in the sense that; the Presidential, Parliamentary and Councilor Candidate who secures the majority of votes is declared to be the winner. However, special seats such as the Women Special Seats Members of Parliament are obtained by way of Proportional Representation according to the number of votes each Party got country-wide in the Parliamentary Election (The National Electoral Commission of Tanzania,2010).

The Elections Expenses Act of 2010 governs the election expenses; it became operational immediately after being assented by the President in early 2010. Therefore, it was used for the first time during the 2010 general elections. This Act makes provisions for the funding of nomination process, election campaigns and elections with a view of controlling the use of funds and prohibited practices in the nomination process. This Act makes provisions for allocation, management and accountability of funds by political parties during elections.

Article 1 of the Constitution of the Republic of Rwanda (2003 amendment), defines Rwanda as "an independent, sovereign, democratic, social and secular Republic". The President is elected on the basis of a single national constituency, requiring a simple majority. An elected term is seven-years, and according to the Constitution amendment, the term limit of two terms has been removed. In terms of national legislation, the key legal instruments for the conduct of the election are: The Constitution of the Republic of Rwanda (2003, as amended); The Presidential Election Law (No. 27/2010); Law on Political Parties; Law No18/2008 of 23/07/2008 Relating to the Punishment of the Crime of Genocide Ideology; Law Relating to the Organization and Functioning of the National Electoral Commission (No. 31/2005); Law on Media (No.22/2009) and Regulation Providing for Access to Public Media during Presidential Election Campaigns.

The National Independent Electoral Commission (NIEC) established by Constitution as an independent body is responsible for the organization of national level, communes and local elections 
including voter registration and management of the voting processes done by secret ballot. Registration undertaken by the NIEC provision is made for the implementation of continuous registration. Party registration is undertaken by Ministry of the Interior and funding by the state is restricted to subsidizing electoral expenses; foreign funding is prohibited; parties must submit annual accounts to the Ministries of Interior and of Finance. The National Council of the Communications must ensure equitable access of all candidates during the campaign period to state owned media.

\section{Statement of the Problem}

Globally, electoral process is an important role in shaping the political stability in any given country. Violating the stipulated code of conduct of the electoral process is dangerous to both the economy and the political stability of a country. This is potential in situations where polls are subject to manipulation or conducted by a biased source hence distortion of poll results. It is well recognized under international law that any limitation placed on freedom of expression must remain within strictly-defined parameters.

For example this is evidenced by the 2007 post-election violence in Kenya that left more than 1,500 Kenyans killed, 1,133 casualties, over 350,000 internally displaced persons, approximately 2,000 refugees, destruction of 117,216 private property and 491 government owned property, around 42,000 houses and many businesses looted and destroyed, gang rapes, and destruction of the railway line (Kioko, 2010) .The lessons learnt however did not live long to help Kenya organize free and fair elections in the 2017 presidential elections.

The situation in Burundi has progressively deteriorated since 25 April 2015. According to the armed conflict location and event data set country report on Burundi crisis (2016), the Burundi political conflict reported fatality count of 1,155 between 26 April 2015 and 25 April 2016. At least 690 of the reported dead (or approximately 60\%) are civilians. More than 260,000 people have reportedly fled outside Burundi and thousands have disappeared without trace: approximately 137,000 Burundian refugees have crossed into Tanzania, 77,000 into Rwanda, 23,000 into Uganda, and 22,000 into the Democratic Republic of Congo (DRC) (UNHCR, 29 April 2016).

According to the Commonwealth Observer Group report on Uganda Presidential and Parliamentary Elections in 2011 and 2016 respectively a number of irregularities in the electoral processes have consistently been noted and they include; lack of a level playing field; abuse of incumbency, the 'commercialization of politics', the lack of campaign finance regulations; the lack of a Political Parties Code of Conduct; issues with regard to the lack of independence of the Electoral Commission and its poor management of the process.

Quantitative cross-national research on the principal manifestations of political instability coups and civil wars has consistently shown that economic conditions are the best predictors in Africa and other developing regions, (Fearon \& Laitin, 2013), (Miguel et al ,2014) and (McGowan, 2014). Although these empirical analyses acknowledge that the weakness of political institutions contribute to the region's volatility, they do not explicitly bring out the factors related to electioneering and leadership positions as possible contributors and the chief strategy used by most African leaders to buy off rivals and reward their followers.

This is attributable to difficulties in operationalization and measurement of indicators of the electoral processes and leadership. From the review it is also worth noting that a few studies have determined the electoral processes. 
INTERNATIONAL JOURNAL OF ACADEMIC RESEARCH IN BUSINESS AND SOCIAL SCIENCES Vol. 8, No. 8, August 2018, E-ISSN: 2222-6990 @ 2018 HRMARS

\section{Objectives and Hypotheses of Study}

The general objective of the study was to examine the role of political leadership in electoral process and political stability in the East African Community States. Specifically, the study sought to determine the relationship between the pre-election phase processes and political stability in the East African Community States. In order to address the above objectives, the following null hypotheses were tested.

Ho1: There is no significant relationship between the pre-election phase and political stability in the East African Community States.

H1: There is significant relationship between the pre-election phase and political stability in the East African Community States.

\section{Theoretical Perspective}

This paper discusses the sequential theory of decentralization upon which the study is anchored

\section{Evolutionary Theory of Political Leadership}

The theory put forward by Smith, \& Conrey, (2010). states that central to social systems are the attitudes of the rank and file toward those who make political decisions (leaders), and attitudes toward leaders are known to be characterized by two fundamental features; the modal attitude and people's variance. The modal attitude is acceptance of the necessity of leaders coupled with acute aversion to leaders who are believed to be motivated by ambition and avarice; second, people are highly variable with some being markedly more sensitive than others to the traits of leaders.

The theory explains that one of the enduring features of modern representative democracy is people's dissatisfaction with political decision makers but with substantial cross-sectional variance within populations. The fact that people always have the desire to be led but at the same time their tendency to be dissatisfied with those who are leaders can be explained using evolutionary biology that given the competitive and uncertain environment in which groups typically exist, leadership is essential mainly because groups without leaders will ultimately lose out to groups with leaders but at the same time, bad leaders can be just as pathological to a group as no leaders at all.

It relates to the fact that in many circumstances when a limited number of individuals possesses special authority to make decisions for others, those individuals are also in a position to direct resources to themselves at the expense of other group members, resulting in a dysfunctional group. To avoid this, members of a successful group need to stand ready not only to elevate and obey leaders but also to keep an unblinking eye on those leaders and to be prepared to cut them down to size if they act in a self-serving fashion or seem to believe they deserve special treatment. This is what builds the essence of democracy and hence political stability.

A study by Yu, Leithwood and Jantzi (2012) concluded that transformational leaders impacted on the followers towards change in the organization and conditions in the organization. This leadership approach is thus superior and necessary for all organizations which plan to make progressive change (Tucker \& Russell, 2014). This theory was adopted by the study to guide and direct how powerful the type of leadership can be through the actions of the leader in determining aspects of the organization such as setting the strategic direction, managing resources and culture. 


\section{Conceptual Framework Independent variables}

\section{Pre-election Phase Processes}

- Election laws

- Political environment on violence and intimidation

- Voter registration

\section{Dependent variable}

\section{Political stability}

- Practice of and respect for rule of law;

- The rights and freedoms of the citizens;

- Free and fair elections;

- Low unemployment and low poverty levels;

- Adherence to and respect for electoral processes

Figure 2.1 Conceptual Framework

\section{Research Methodology}

A research design is the arrangement of conditions for collection and analysis of data in a manner that aims to combine relevance to the research purpose with economy (Kombo \& Tromp, 2011). According to Kothari, 2011, a research design is a series of advance decisions that when pieced together form a specific master plan or model for the conduct of the investigation. The function of a research design therefore is to ensure that the evidence obtained enables the researcher to effectively address the research problem logically and as unambiguously as possible. Sekaran, (2009) sees a research design as the logical sequence that links the empirical data to a study's initial research questions and as such, the study design discourages the situation in which the evidence is disconnected from the initial research questions.

The choice of a sample size is mainly cash on the need for accuracy required by the researcher and the degree of variation (Saunders et al., 2009). A sample size of 94 respondents was determined using Slovin's formula (1967)

Table 1: Sample Distribution

$$
\begin{aligned}
& n=\frac{N}{1+N(e)^{2}}
\end{aligned}
$$

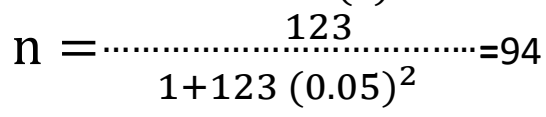

\begin{tabular}{lcc}
\hline Organization & Total Population & Sample size \\
\hline EAC Legislative Assembly & 54 & 41 \\
Clerks & 18 & 14 \\
Public relations & 12 & 9 \\
Accountants & 6 & 5 \\
Researchers & 10 & 8 \\
IT managers & 15 & 11 \\
Hansards & 8 & 6 \\
Total & 123 & 94 \\
\hline
\end{tabular}

Source: Secondary data (2017)

Questionnaires were the main tools for collecting the primary data since the study were concerned with variables that cannot be directly observed such as views, opinions, perceptions and feelings of 
INTERNATIONAL JOURNAL OF ACADEMIC RESEARCH IN BUSINESS AND SOCIAL SCIENCES

Vol. 8, No. 8, August 2018, E-ISSN: 2222-6990 @ 2018 HRMARS

the respondents which are best collected by this technique (Touliatos \& Compton, 2013). Questionnaires provide a high degree of data standardization and adoption of generalized information amongst any population (Schutt, 2015). He further explains that questionnaires are useful in a descriptive survey study where there is need to get information from people quickly and easily in a non-threatening way. The study expected to produce both quantitative and qualitative data. Therefore, both descriptive and inferential statistics were used to analyze the data. Once the questionnaires were received they were coded and edited for completeness and consistency. The data obtained was cleared and coded then SPSS was used for data analysis using quantitative data analysis as well as qualitative data analysis. The study collected and analyze primary data which was keyed into an excel table, before subjected to meaningful analysis through SPSS Version 21 . The process involved the identification and correcting of errors in the data (data cleaning), coding the data and storing it in excel form. Data was coded and analyzed simultaneously using content analysis method. A list of key categories and themes for each variable were generated and this helped to guide the nature of integration needed for the qualitative data processed.

A. Pre-election phase processes and political stability

This section presents the Coefficients of, the line of best fit, Regression Analysis and ANOVA for preelection phase processes.

\section{Coefficients of pre-election phase processes.}

The coefficients of pre-election phase processes are presented in Table 2 which indicate that the model has a significant $p$-value $=.000$. The study at $95 \%$ confidence interval solved the first research question by indicating that the variable pre-election phase processes is statistically significant in the political stability.

Table 2: Coefficients of pre-election phase processes.

\begin{tabular}{lcccc}
\hline Model & $\begin{array}{c}\text { Unstandardized } \\
\text { Coefficients }\end{array}$ & $\begin{array}{c}\text { Standardized } \\
\text { Coefficients }\end{array}$ & T & Sig.
\end{tabular}

\begin{tabular}{llccccc} 
& B & $\begin{array}{c}\text { Std. } \\
\text { Error }\end{array}$ & Beta & & \\
\hline 1 & & & & & \\
& (Constant) & .773 & .231 & & 5.973 & .000 \\
& $\begin{array}{l}\text { Pre-election phase processes } \\
\text { (X1) }\end{array}$ & .539 & .062 & .444 & 8.815 & .000 \\
& & & & &
\end{tabular}

a. Dependent variable: Political stability

Using the summary of Coefficients presented in Table 2 , a linear regression model of the form, $Y=\alpha$ $+\beta$ Xi can be fitted as follows:

$\mathrm{Y}=0.773+0.539 \times 1$ Equation 1

\section{Regression Analysis for pre-election phase processes}

Regression analysis was performed in order to determine whether the independent variable, preelection phase processes could be reliable for explaining the change in the dependent variable, 
INTERNATIONAL JOURNAL OF ACADEMIC RESEARCH IN BUSINESS AND SOCIAL SCIENCES

Vol. 8, No. 8, August 2018, E-ISSN: 2222-6990 @ 2018 HRMARS

political stability in East Africa region. The coefficients obtained indicate that the correlation coefficient $(R)$ between the independent variable and the political stability was 0.994 which is a positive correlation relationship. Table 3 shows a coefficient of determination $\left(R^{2}\right)$ of 0.570 , which means that this variable alone can explain up to $57.0 \%$ of the variations in the dependent variable, political stability.

Table 3: Model summary showing pre-election phase processes

\begin{tabular}{lllll}
\hline Model & $\mathrm{R}$ & $\mathrm{R}$ Square & Adjusted R Square & Std. Error of the Estimate \\
\hline 1 & $.755^{\mathrm{a}}$ & .570 & .567 & .65724
\end{tabular}

a. Predictors: (Constant), Pre-election phase processes

\section{ANOVA for pre-election phase processes}

The results of an ANOVA test performed on the variable pre-election phase processes are summarized in Table 4 which shows that the variable has a P-value equal to 0.000 , indicating that the model is statistically significant in explaining the change in the dependent variable, considering that the P-value is less than 0.05 at the $95 \%$ level of confidence. Therefore, based on the empirical results presented in Table 4, the Alternative Hypothesis H1is accepted and the null Hypothesis (H01) is rejected and a conclusion reached that, at $5 \%$ level of significance, pre-election phase processes significantly influence the political stability.

Table 4: ANOVA for pre-election phase processes

\begin{tabular}{lllllll}
\hline Model & & Sum of Squares & Df & Mean Square & $\mathrm{F}$ & Sig. \\
\hline \multirow{4}{*}{1} & Regression & 42.431 & 1 & 42.431 & 201.134 & $.000^{\mathrm{a}}$ \\
& Residual & 33.811 & 52 & .617 & & \\
& Total & 76.242 & 53 & & & \\
\hline
\end{tabular}

b. Dependent Variable: Political stability

c. Predictors: (Constant), Pre-election phase processes

\section{Conclusion on Pre-election phase processes and political stability in the East African Community} States.

The first objective was to determine the relationship between the pre-election phase processes and political stability in the East African Community States. The findings confirm that there is a statistically significant influence of pre-election phase processes and political stability in the East African Community States. A positive increase in pre-election phase processes leads to an increase in political stability in the East African Community States. It can be concluded from this study that pre-election phase processes were statistically significant in explaining political stability in the East African Community States. The study concludes that EAC law and regulation on elections and political leadership are effective. EAC law and regulation on elections and political leadership are adequately implemented. The constitutional of all the EAC states cover all the aspect of election and political leadership. 
INTERNATIONAL JOURNAL OF ACADEMIC RESEARCH IN BUSINESS AND SOCIAL SCIENCES Vol. 8, No. 8, August 2018, E-ISSN: 2222-6990 @ 2018 HRMARS

\section{Recommendations}

Recommendation for improvement can be drawn from the study conclusions; Role of political leadership was reported to be persistent in the study area, the government should consider extending the law branch to the rest of the East Africa Community state through screening, supporting of law moderation groups locked out by stringent East Africa Community state program approval procedures in order to ensure that most people are reached out in the program. This will not only expand the coverage but increase the number of people in pre-election phase. The stakeholders should ensure decision making is inclusive in order to capture the needs of the beneficiaries for posterity of the program.

\section{Areas for Further Research}

The study examined the role of political leadership in electoral process and political stability in the East African Community States. Completion of this study will hopefully motivate interests on further research on the electoral process and election management in particular. As observed by Mosaffar Jaffer, this is an area which is under researched and hence lack of clarity on the dynamics of election management.

1. A study on other factors influencing effecting planning for general elections and donor support and effective planning for general elections.

2. Determination of the extent to which legislation influences voter's access to credible, reliable and representative polls

3. An investigation of the role of communication in creating awareness about electoral process in East Africa Community States.

\section{References}

Ayanda A., \& Odunayo B. (2015) Comparative Study of Presidential Elections in Nigeria Global. Journal of Human Social Sciences: F Political Science.

Acemoglu, D. and Robinson, J. (2010). Why Did the West Extend the Franchise?

Democracy, Inequality, and Growth in Historical Perspective, Quarterly Journal of Economics 115, 1167-1199.

Acemoglu, D. and Robinson, J., (2016). Economic Backwardness in Political Perspective, American Political Science Review 100, 115-131.

Ades, A.and Di Tella, R. (2009). Rents, Competition, and Corruption, American Economic Review 89, 982-983.

Aila. F \& Ombok, B. (2015). Validating Measures in Business Research: Practical Implications. International Journal of Science and Engineering. 1(9), 11-19.

Ake,C. (2005). Socio Political Approaches and Policies for Sustainable Development in Africa. A paper delivered at the Annual Meeting Symposium of the African Development Banks, Abuja.

Albertyn, C, Hassim, S and Meintjes S. (2012). Women's participation in electoral processes: South Africa in global perspective, in EISA op cit, pp 17-26.

Aubyn, F. and Abdallah, M. (2013). Sustaining Peace and Stability: Appraising the Role of the National Election Security Task Force in the 2012 Elections. Journal of African Elections, Vol. 12, No. 2, 132-153.

Baets, W. (2011). Leadership and Public Governance: Complexity, uncertainty and Bass, B. M. \& Bass, R. (2008). Handbook of leadership theory, research and application. New 
INTERNATIONAL JOURNAL OF ACADEMIC RESEARCH IN BUSINESS AND SOCIAL SCIENCES

Vol. 8, No. 8, August 2018, E-ISSN: 2222-6990 @ 2018 HRMARS

York: Free Press

Bekoe, D. (2010). Trends in Electoral Violence in Sub-Saharan Africa, Washington, D.C.:

United States Institute of Peace (USIP).

Benoit, K. (2014) 'Models of Electoral System Change', Electoral Studies 23(3): 363-389.

Birch, S. (2010). Patterns of Electoral Malpractice. Working Paper No.4. Project on

Malpractice in New and Semi-Democracies. University of Essex.

Blais, A., Massicotte, L., (2010). Electoral systems. In: LeDuc, L, Niemi, R.G., Norris, P.

(Eds.), Comparing Democracies: Elections and Voting in Global Perspective. Laurence LeDuc, Sage, Thousand Oaks, CA, p. 49-82.

Blau, D \& Adrian, B. (2008). Electoral Reform in the UK: A Veto-Player Analysis. In

André Blais (ed.). To Keep or To Change First Past the Post? The Politics of Electoral Reform.

Oxford: Oxford University Press, p. 61-89.

Blomme, R. J., Kodden, B. \& Suffolk, A. B. (2015). Leadership theories and the concept of work engagement: Creating a conceptual framework for management implications and research. Journal of management and organizational behaviors, 21 (2), 125-144.

Boix, C. and Milan, S. (2009). Non - tyrannical Autocracies. Paper presented at the UCLA Comparative Politics Seminar.

Booth, D. (2011). Governance for development in Africa: building on what works.

Bratton, M. (2010) 'Anchoring the "D-Word" in Africa', Journal of Democracy, 21, 4, p. 108.

Bratton, M. (2008), Vote Buying and Violence in Nigerian Election Campaigns, in: Electoral Studies, 27, 621-632.

Brooks, C. (2011). Introductory Econometrics for Finance. 2nd Ed). Cambridge: Cambridge University Press,

Bryman, A. (2011). Social Research Methods. New York: Oxford Publishers

Bryman, A., \& Bell, E. (2009). Business Research Methods. Oxford: Oxford University Press.

Burns, J. M. (2008). Leadership. New York, NY: Harper \& Row.

Burns, R, A., \& Burns, R. (2012). Business Research Methods and Statistics using SPSS. London: Sage Publications Ltd

Chang, E. (2008). Electoral Incentives and Budgetary Spending: Rethinking the Role of Political. New York, NY: Harper \& Row.

Cheeseman, N. (2014). Democracy in Africa: Successes, Failures, and the Struggle for Political Reform. Cambridge University Press.

Clionadh, R. Roudabeh. K, McKnight. J \& James.M. (2016). Armed conflict location and event data set country report on Burundi crisis p.1-5

Cooper, D. \& Schindler, P. (2011). Business Research Methods. New York: McGraw Hill. Cronbach, L.J. (1990). Essentials of Psychological Testing, $5^{\text {th }}$ Ed. New York.

Cyert, R. M., \& March, J. G. (2013). A behavioral theory of the firm. NJ: Englewood Cliffs.

Dailon, R. (2011). Statistical Design and Analysis of Experiments for Development Research, lowa: Brown publishing.

Damania, R. and Bulte, E. (2013). Resources for Sale: Corruption, Democracy and the Natural Resource Curse, Mimeo, University of Adelaide. Democratization 13(4): 584-604.

Davis, J. S. (2011). Challenging governance theory: From network to hegemony. New Denhardt, J. V, \& Denhardt, R. B. (2003). The new public service: Serving, not steering. Diamond, L. (2009). Developing Democracy Toward Consolidation. Baltimore: Johns 
INTERNATIONAL JOURNAL OF ACADEMIC RESEARCH IN BUSINESS AND SOCIAL SCIENCES Vol. 8, No. 8, August 2018, E-ISSN: 2222-6990 C 2018 HRMARS

distribution. Journal of Modern African Studies, 41(3), 339-370.

EISA, (2012). Pre-Election Assessment Mission to Ghana: Report, unpublished.

Election Commission of India (2014), Proposed Electoral Reforms, New Delhi: Nirwachan

Sadan.

Election Commission of India (2009), Model Code of Conduct for the Guidance of Political Parties and Candidates. New Delhi Nirwachan Sadan.

Election Expenses Act, (2010), [www] http://www.parliament.go.tz/Polis/PAMS/Docs/62010.pdf [PDF document, opens new window] (accessed 24 May 2016).

Elections in Burundi, (2015). Moment of Truth Crisis Group Africa Report N²24, 17 April. European Union Election Observation Mission (2015). Final Report of the 2015 General Elections in the United Republic of Tanzania. Pages 1-10.

Fearon, J. D., \& Laitin, D. D. (2013). Ethnicity, insurgency, and civil war. American Political Science Review, 97(1), 75-90.

Frantz, E. and Geddes, B., (2013). 'Latin America's authoritarian drift: The threat from the populist left', Journal of Democracy, 24/3 pp. 18-32

Freeman, R. E. (2010). Strategic Management: A Stakeholder Approach. Cambridge University Press, New York.

Fox J, Shotts KW (2009). Delegates or trustees? A theory of political accountability. J. Polit. 71(4):1225-37

Gastil, J. (2014). A definition and illustration of democratic leadership. Human Relations, 47, $p p$ 504-521.

Ghauri, P. Gronhaug, K. (2010). Research Methods in Business Studies: A Practical

Gill, M. S. (2009). Electoral Systems in India. Available at http://eci.nic.in/eci_main/eci_publications/books/miscell/ESI-III.pdf.Last viewed on 27th October 2016.

Global Peace Index, (2015). Institute of Economics and Peace.

Grofman, B, S. Bowler, and Blais, A. (2009). Duverger's Law of Plurality Voting: The Logic of Party Competition in Canada, India, the United Kingdom and the United States. New York: Springer.

Gujarat, D. N. (2011). Basic Econometrics, (6th Ed.). Boston. The McGraw-Hill Companies.

IFES, (2015). Residential Elections Act 2000.www.ulii.org. Retrieved 2016-02-08. Instrumental variables approach. Journal of Political Economy, 112(4).725-753.

International Institute for Democracy and Electoral Assistance (International IDEA) (2017). The Global State of Democracy2017: Exploring Democracy's Resilience (Stockholm: International IDEA, 2017),

IPU, (2015). Electoral system. International Conflict Resolution No. 2. Washington, DC: National Academy Press.

Judge, T. A., \& Piccolo, R. F. (2014). Transformational and transactional leadership: Ametaanalystic test of their relative validity. Journal of Applied Psychology, 8 (5), 755 -768.

Kadima, D and Matlosa, K (2009) The Roles of Regional Organizations in Elections in Africa Kapur AC (2009). Principles of Political Science New Delhi: S Chand.

Kathurima, M. (2011). The Kenya Electoral system. ALRAESA Workshop on Model Electoral Laws Swakopmund, Namibia, 26-27July 2011

Katz, R.S. (2015). Why are there so many (or so few) electoral reforms? In: Michael Gallagher and Vcx 
INTERNATIONAL JOURNAL OF ACADEMIC RESEARCH IN BUSINESS AND SOCIAL SCIENCES

Vol. 8, No. 8, August 2018, E-ISSN: 2222-6990 @ 2018 HRMARS

Khamisi, J. (2011). The politics of betrayal: Diary of a Kenyan Legislator. USA: Trafford Publishing. Leiden: Koninklijke Brill NV.

Kilonzo, S. (2009). "Ethnic Minorities Wedged Up in Post-Election Violence in Kenya: A Lesson for African Governments." Critical Arts: A South-North Journal of Cultural \& Media Studies 23, no. 2 245-251.

Kombo, D. K., \& Tromp, D. L. (2011). Proposal and Thesis Writing; An Introduction. Nairobi: Paulines Publications Africa.

Kothari, C.R. (2011). Research Methodology; Methods and Techniques. New Delhi: New Age International Publishers.

Kothari, C.R. (2004). Research Methodology: Methods and Techniques, NewDelhi: New age International, Pp.31-52

Kribat, M., Burton, B., \& Crawford, L. (2013). Evidence on the nature, extend and determinants of disclosures in Libyan banks' annual reports. Journal of Accounting in Emerging Economies, $3(2), 88-114$.

Kura BY (2014). Clientale Democracy: Political Party Funding and Candidate Selection in Nigeria. African Journal of Political Science and International Relations.

Lamin, Abdul Rahaman (2011), West Africa in Context: Elections and Challenges of Democratic Governance, in: Journal of African Elections, 10, 2.

Lavrakas, P. J. (2013). Encyclopedia of Survey Research Methods. (Volume 1). Thousand Oaks, CA: Sage Publications.

Lindberg, S. I. (2010). What Accountability Pressures Do MPs in Africa Face and How Do they respond? Evidence from Ghana. Journal of Modern African Studies, 48(1), 117-142. http://dx.doi.org/10.1017/S0022278x09990243

Likert, R. (1832). A Technique for measurement of attitudes. Archives of Psychology No. 40.

Lindberg, S. (2010). Some evidence on the demand side of private-public goods provision by MPs.

Lwaitama, A. (2012). Political Parties and Citizens' Participation in EAC Integration. Synthesis of the Findings Drawn from Five Country Studies. In Youth, Democracy and Legal Reform Processes: Articles from FES Political Handbooks 2013, 2012.

Marshall, C., \& Rossman, G.B. (2010). Designing qualitative research. New York: Sage Publications

Matlosa, K \& Sello, N, 'Political parties and democratization in Lesotho', EISA Research Report No. 23, (Johannesburg: EISA, 2005), p. 24.

Mbaku JM (2010). Bureaucratic and Political Corruption in Africa: The Public Choice Perspective Malabar: Kreiger Publishing.

McGowan, P. J. (2014). African military coups d'etat, 1956-2001: Frequency, trends and

McQuail, D. (2015). McQuail's Mass Communication Theory, Sage Publication, London.

Michael Krennerich (2012). Germany: The Original Mixed Member Proportional System. http://www.idea.int/esd/upload/germany.pdf.

Miller,M.L .(1986). Reliability and Validity in Qualitative Research. Beverly Hills: sage Publication.

Mudde, C., (2013). 'The 2012 Stein Rokkan Lecture. Three decades of populist radical right parties in Western Europe: So, what?', European Journal of Political Research, 52/1, pp. 1-19

Mudde, C. and Kaltwasser, C. R., (2013). 'Populism', in M. Freeden and M. Stears (eds), Oxford Handbook of Political Ideologies (Oxford: Oxford University Press) 
INTERNATIONAL JOURNAL OF ACADEMIC RESEARCH IN BUSINESS AND SOCIAL SCIENCES Vol. 8, No. 8, August 2018, E-ISSN: 2222-6990 @ 2018 HRMARS

Mugenda, O. M., \& Mugenda, A. G. (2008). Research methods: Quantitative and qualitative approaches. Nairobi-Kenya: Acts Press.

Mugenda, O.M., \& Mugenda, A.G. (2013). Research methods. Nairobi: McMillan Publishers.

Muhula, R. (2009). Horizontal Inequalities and Ethno-regional politics in Kenya. Kenya Studies Review: 1(1) 85-105.

Munday, J. (2009). Introducing translation studies: Theories and applications. New York: Routledge

Mukandala, R. \& Killian, B. (2004). Political Cooperation in East Africa, in S.S.

Mutua Kioko.P. (2010). A Study on the Post-Election Violence in Kenya, an International Law Perspective Ph.D thesis p.20-30

Mwangola, M. S. (2013). Leaders of tomorrow? The youth and democratization in Kenya in Kenya: the struggle for democracy. London and New York: ZED books

National Electoral Commission, (2010). Electoral Code of Conduct for the Presidential, Parliamentary and Councilors. Elections.

National Electoral Commission, (2010). Guidelines for local and international Election observers.

Ngari, C. (2017). Relationship between Workplace Chronemic Culture and Employee Performance among Service State Corporations in Kenya.

Ngowi, H. P. (2009). Economic development and change in Tanzania since independence: The political leadership factors. African Journal of Political Science and International Relations, 3(4), 259-267.

Nicole. S and Monroe, E. (2009). Media, Elections and Political Violence in Eastern Africa: Towards a Comparative Framework. University of Oxford Center for Global Communication Studies, Annenberg School for Communication.p1-25

Norman, S. King (2013). African development bailout: Striking a balance between religion, peace and tranquility. International Journal Social Science Research. Vol.2 (5), 55-65

Norris. P, (2006). Revisiting the theories of the state first developed by Marx, Engels and especially Lenin in his work. The State and Revolution.

Norris, P. (2002). Democratic Phoenix: Reinventing Political Activism. Cambridge: Cambridge University Press. Oaks, CA: Sage Publications, Inc.

Obazee G (2014) The Effects of Corruption on the Inflow of Foreign Direct Investment into Ten Sub-Saharan African Countries: Using Ghana and Nigeria as Discussion Points PhD Thesis submitted to the Faculty of Wilmington University

Obi, C. (2008), International Election Observer Missions and the Promotion of Democracy: Some Lessons from Nigeria's 2007 Elections, in: Politikon, 35, 1, 69-86.

Odhiambo, F. (2009) The 2007 General Elections in Kenya: Electoral Laws and Processes. Journal of African Elections 7 (2), pp.113-123

Ogbeidi, M. M. (2012). Political leadership and corruption in Nigeria since 1960: A socioeconomic analysis. Journal of Nigerian Studies, 1(2), 1-25.

Olorunmola A (2016). Cost of Politics in Nigeria Westminster Foundation for Democracy

Olopade, D. (2014). The bright continent and making change in modern Africa. London: Duckworth overlook

Omilusi M, Adu AOP (2016). Party Politics and Democratic Governance in Nigeria: Historical Perspective, International Journal of Multidisciplinary Academic Research Organization for Economic Countries and Development (OECD) Publication. 
INTERNATIONAL JOURNAL OF ACADEMIC RESEARCH IN BUSINESS AND SOCIAL SCIENCES

Vol. 8, No. 8, August 2018, E-ISSN: 2222-6990 @ 2018 HRMARS

Oyedele, O. A. (2012). The challenges of infrastructure development in democratic governance. Constructive Economics and Management,1(6119), 1-15. Retrieved from www.fig.net/TSOIC

Oso, W. \& Onen, D. (2011). A General Guide to Writing Research Proposal and Report; Handbook for Beginning Researchers. Nairobi: Jomo Kenyatta Foundation.

Parliamentary Education Office, (2009). Fact sheets for students http://www. peo.gov.au/students/fss/index.html.

Patton, M. Q. (2009). Qualitative evaluation and research methods (3rd ed.). Thousand Pawell, Ponzio, Richard. (2011). Democratic peacebuilding: aiding Afghanistan and other fragile states. Oxford; New York: Oxford University Press.

Reno, William (2011). Warfare in independent Africa. Cambridge; New York: Cambridge University Press.

Resnick, D. and Casale, D. (2011). The Political Participation of Africa's Youth. Turnout, Partisanship, and Protest. Working Paper No. 2011/56. Helsinki: UNU-WIDER.

Reynolds A \& Carey J.M. (2012), 'Getting elections wrong', Journal of Democracy, 23, $1,2012$.

Reynolds, A. (2009) Electoral systems choices for South Africa beyond 1999, in EISA (ed) Electoral Systems.

Robert, Henry M.; et al. (2011). Robert's Rules of Order Newly Revised (11th ed.). Philadelphia, PA: Da Capo Press. pp. 438-446.

Rotberg, R. (2012). Transformative Political Leadership: Making a Difference in the Developing World. Chicago and London: University of Chicago Press.

Royston, J. P. (2012). An extension of Shapiro and Wilk's W test for normality to large samples. Applied Statistics, 115-124.

Saboe, K. N., Taing, M. U., Way, J. O., \& Johnson. R. E. (2015). Examining the unique mediators that underlie the effect of different dimensions of transformational leadership. Journal of leadership and organizational studies, 22 (2), 175 -186.

Saunders, M., Lewis, P., \& Thornhill, A. (2009). Research methods for business students. (5th Ed.). London: Prentice Hall.

Schutt, R.K. (2015). Investigating the Social World: The Process and Practice of Research. London: Sage Publications

Sekaran, U. \& Bougie, R. (2011). Research Methods for Business: A Skill Building Approach. Delhi: Aggarwal printing press,

Shri Mohan Singh, M.P. (2011). The constitution Amendment Bill. As introduced in the Rajya Sabha on $5^{\text {th }}$ August 2011. P.2.

Shriberg, D. \& Shriberg, A. (2011). Practicing leadership: Principles and applications. 4th (Ed.). U.S.A: Thompson digital.

Shugart, M.S. (2005) 'Comparative electoral systems research: the maturation of a field and new challenges ahead', in M. Gallagher and P. Mitchell (eds.) The Politics of Electoral Systems, Oxford: Oxford University Press, 25-56.

Smith, D. (2011). The re-demarcation and reapportionment of parliamentary constituencies in Ghana. CDD-Ghana Briefing Papers, 10(2), 1-12.

Smith, E. R., \& Conrey, F. R. (2010). Mental representations are states, not things: Implications for implicit and explicit measurement. In B. Wittenbrink \& N. Schwarz (Eds.), Implicit measures of attitudes (pp. 247-264). New York: Guilford Press 
INTERNATIONAL JOURNAL OF ACADEMIC RESEARCH IN BUSINESS AND SOCIAL SCIENCES

Vol. 8, No. 8, August 2018, E-ISSN: 2222-6990 @ 2018 HRMARS

Stokes SC (2013). Clientelism in Oxford Handbooks Online the Centre for Public Policy Alternatives (CPPA) Presidential Election Outcome: Analyses and Implications, Transparency International Report.

Suhas P. (2012). Elections in India Prestige deriving from practice. Institute for Research and Debate on Governance. Paris: Charles Léopold Mayer Publishing House.

Teorell, J \&Lindstedt, C (2010). Measuring electoral systems. Political Research Quarterly, Vol. 63, No2. (pp. 434-448).

Thad E. H. (2012). Primer on the U.S. Election System pp.3-25. University of Utah Salt Lake City, Utah, USA

The National Electoral Commission of Tanzania, (2010) The electoral process in East Africa Tanzania's perspective. The National Elections Act, Cap 343, the Local Authorities Act, Cap 292 pp.2-22

Touliatos, J., \& Compton, N. H. (2013). Research methods in human ecology/home economics. Ames: lowa State University Press

Tucker, B.A., \& Russell, R.F. (2014). The influence of the transformational leader. Journal of Leadership \&Organizational Studies, 10(4), 103-111.

Uddin, M. N. \& Hamiduzzan, M. (2009). The philosophy of Science in Social Research. The Journal of International Social Research, 2(6).

Uganda Law reform commission, (2011). Country report on Electoral systems in Uganda.

Ukase P. (2015) Political Parties and Election /Campaign Financing in Nigeria: Interrogating the General Elections.

United States Department of State Bureau of Democracy, Human Rights and Labor (2015). Country Reports on Human Rights Practices. p 18-22

USAID, UKAID (2015). Still Above the Ceiling: A Report on Campaign Finance and Use of State Administrative Resources in the Presidential Election, Centre for Social Justice.

Wagner, Wolfgang, and Sofie Dreef. (2013). "Ethnic Composition and Electoral System Design: Demographic Context Conditions for Post-conflict Elections." Ethnopolitics:1-20. doi: 10.1080/17449057.2013.793883.

$\mathrm{Xu}, \mathrm{Z}$. and Li, H. (2008) 'Political freedom, economic freedom, and income convergence: Do stages of economic development matter?', Public Choice, 135, pp. 183-205.

Yu, H., Leithwood, K., \& Jantzi, D. (2012). The effects of transformational leadership on teachers' commitment to change in Hong Kong. Journal of Educational Administration, 40(4), 368-89.

Zikmund, G.W., Babin, B.J., Carr, C.J., \& Griffin, M. (2010). Business research methods. (8th ed.). South-Western, Cengage Learning. 